\title{
White coat narcissism
}

I met Carleton Gadjusek at a dinner party in Toronto in the mid-1970s, before he received his Nobel Prize. He sat at the head of a long table and talked non-stop, so no one else could speak. I remember thinking "what a windbag." He seemed to feel that he was the smartest person at the table (which was probably correct) and that, therefore, he had a right to monopolize the conversation. It was that corollary I had trouble with. I have had dinner with other smart (and not so smart) people who operated under the same assumption.

In the mid-1950s, Gadjusek, an American pediatrician who had developed an interest and expertise in infectious disease, was doing a stint in Melbourne, Australia with Frank Macfarlane Burnet, the famous Australian virologist, who described Gadjusek in the following way: "Intelligence quotient up in the 180s and the emotional immaturity of a 15-year-old. ... completely self-centred ... thick-skinned ... inconsiderate. ... won't let other people's feelings interfere in the least with what he wants to do."

Burnet, who, with Peter Medawar, was soon to receive the Nobel Prize for demonstrating acquired immune tolerance, sent Gadjusek to Papua, New Guinea to study the Fore tribe among whom a neuromuscular disease, locally called kuru, was claiming lives. The indigent population attributed the disease to witchcraft, a deliberate black magic attempt by enemy tribes to stop Fore women from conceiving. Australian medics thought that the behaviours of kuru sufferers (flailing, falling, posturing, shaking, laughing) were imitations of drunkenness and that kuru, therefore, was a form of "cargo cult." A cargo cult is a religious practice that anthropologists had previously observed in several remote parts of New Guinea. The practice develops

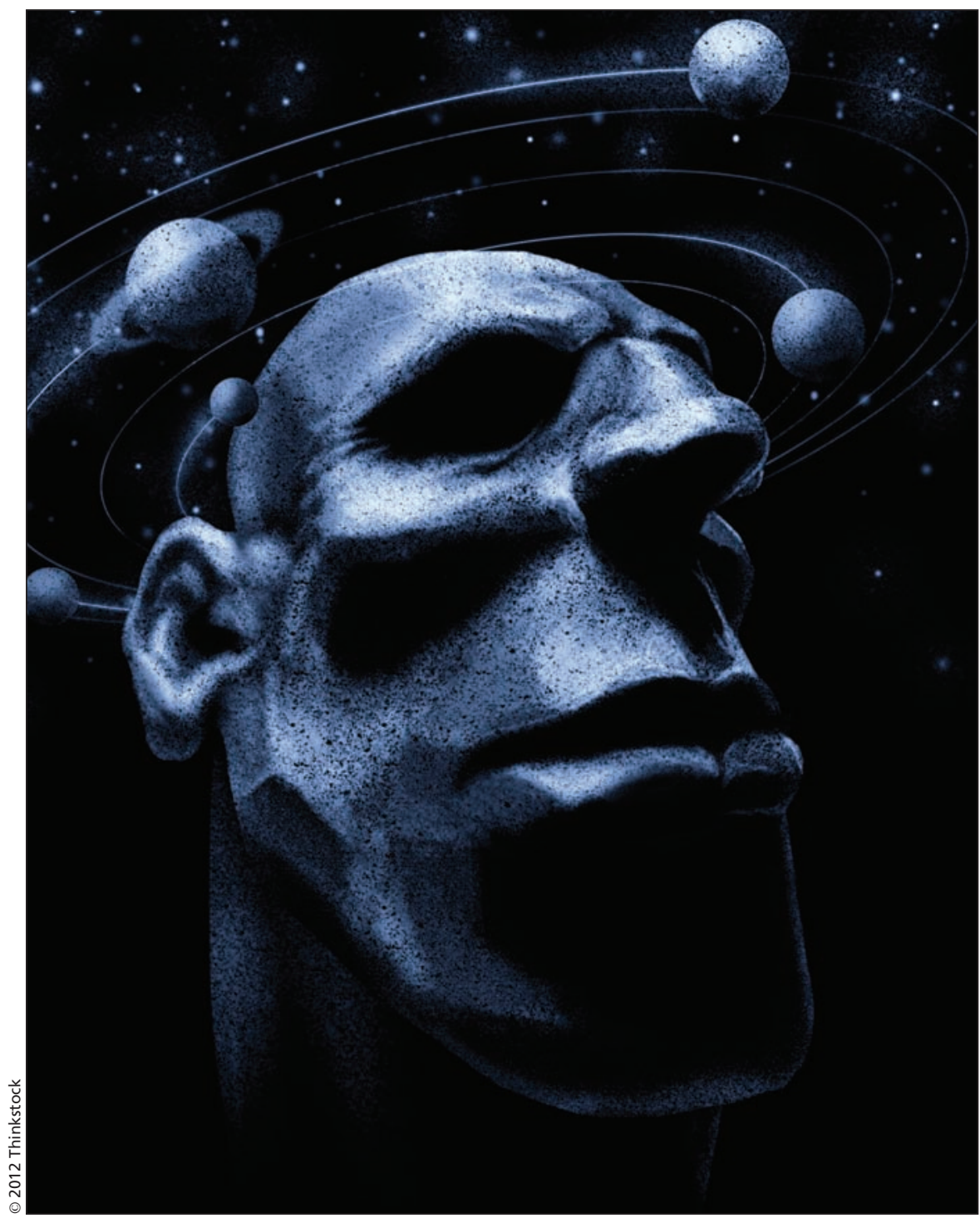

among a segment of traditional society upon contact with more advanced civilizations. The newcomers, who come by air, are viewed as supernatural suppliers of advanced technology and know-how. Cult members begin to imitate the behaviour of the newcomers in the hope of thereby acquiring the new resources for themselves. The fact that the behaviours, in the case of kuru, led to inevitable death made Australian medical officials suspect that it was something other than a cargo cult and, hence, the arrival of Dr. Gadjusek. He believed at first that kuru could be a genetic disease, but he was puzzled by the demographics — 25:1 in favour of women, he noted in one early report, with an equal sex ratio in children.

Reading reports of anthropologists, Gadjusek noted that, in the recent past, when someone died, women and children participated in mourning rituals that included the preparation and inges- 
tion of the deceased person's remains. The men of the community believed that eating human flesh made them vulnerable to enemies, so did not take part in the feast. On the other hand, they encouraged the women to eat because, they reasoned, dead bodies fertilize the ground. Therefore, by analogy, eating corpses would increase women's fertility (i.e., reverse the sorcery). The practice had been outlawed by the time Gadjusek arrived in New Guinea but he realized that it was the key to the mystery of kuru.

Gadjusek tried, at first unsuccessfully, to transmit what he now believed to be a virus from the blood of kuru victims to experimental animals. In 1967, he reported success. Seven of eight chimpanzees inoculated with the victims' blood came down with kurulike symptoms. Gadjusek called the infective agent a slow virus because it took two to three years to "take" in chimpanzees. ${ }^{2}$ In 1976, Gadjusek was awarded the Nobel Prize in Physiology or Medicine "for the discovery of a new class of human diseases caused by unique infectious agents." Gadjusek's "slow viruses" are now called prions (proteinaceous infectious particle), a term coined by Stanley Prusiner, which (not coincidentally for those familiar with white coat narcissism) incorporates the first two letters of his surname. Prusiner characterized these agents as self-replicating, but lifeless, and won a Nobel of his own in 1997.
Gadjusek used the $\$ 80000$ he received from the Nobel Foundation to bring almost 60 Micronesian youngsters, mostly boys, to be fostered and educated in the United States. The story has been told in a 2009 BBC documentary directed by Bosse Lindquist and entitled The Genius and the Boys. Some of the boys, and Gadjusek himself, are seen in the film, although he was dead a year by the time the film first aired. Apparently Gadjusek, an amateur anthropologist, had written in the scientific journals that he donated to the National Institutes of Health (NIH) "that young boys [in Micronesia] must ingest semen to become strong and virile." His journals implied that he himself took part in the practices. Someone from NIH brought the journal entries to the attention of a US Senate investigation on child pornography ${ }^{1}$ and the FBI contacted one of the fostered boys (now an adult). A taped telephone conversation with Gadjusek ensued in which he stated he was "a pedophile." Gadjusek was charged, pleaded guilty to sexual abuse of a minor, and spent 1997, the year that the Nobel went to Prusiner, in prison.

In the 2009 BBC documentary, Gadjusek fiercely defends himself. Sex between men and boys was an everyday part of long initiation rites in the boys' culture; the boys approached him, not the other way around; no one was harmed. Essentially he is doing on film what he did in Toronto at the dinner table — talking over everyone, edu- cating the less well-informed, not caring what anyone else has to say.

His scientific genius did not protect him from narcissism. His extraordinary achievements may, in fact, have reinforced personality traits that were probably there from childhood: an inflated self-esteem, powerful self-absorption and grandiosity. He was a self-promoter with an unrealistic sense of entitlement, excessively high goals, and an inability to control his impulses. The impulsivity may explain his self-defeating behaviours. This polymath, scientist and ethnographer had intensively studied other cultures, but hadn't bothered, or didn't consider it necessary, to understand or conform to his own.

\section{Mary V. Seeman OC MDCM DSc}

Graduate Coordinator

Institute of Medical Science

University of Toronto

Toronto, Ont.

\section{References}

1. Gillis J, Spinner J. A life of rare purpose and passion. Doctor's work in exotic lands led to Nobel prize, suspicions about relations with children. Washington Post 1996 Apr. 26. Available: http://poundpuplegacy.org/node/26220 (accessed 2011 June 27).

2. Gajdusek DC, Gibbs CJ, Alpers M. Transmission and passage of experimenal "kuru" to chimpanzees. Science 1967;155:212-4.

This essay won third prize in the 2011 ARS Medica and CMAJ Humanities Poetry and Prose contest, announced at the 2011

Canadian Continuing Education Conference.

CMAJ 2012. DOI:10.1503/cmaj.110984 